\author{
E. GHOTBI RAVANDI ${ }^{1}$, F. REZANEJAD ${ }^{1}$, E. DEHGHAN ${ }^{2}$ \\ ${ }^{1}$ Department of Biology, Faculty of Sciences, Shahid Bahonar University of Kerman, Iran \\ E-mail: elnaz.ghotbi@gmail.com \\ ${ }^{2}$ Department of Plant Biotechnology, Faculty of Agriculture, Ferdowsi University of Mashhad, Iran
}

\title{
IN VITRO REGENERATION ABILITY OF DIPLOID AND AUTOTETRAPLOID PLANTS OF CICHORIUM INTYBUS L.
}

\begin{abstract}
Polyploidy has played a significant role in the evolutionary history of plants and is a valuable tool for obtaining useful characteristics. Because of the novelty of polyploids, comparison of their in vitro culture response with diploids would be notable. In this study, leaf explants from diploid, autotetraploid and mixoploid plants of Cichorium intybus L. were cultured in vitro on the similar media and under same conditions. The ploidy level of the obtained calluses and regenerants were determined by flow cytometry analysis. The callogenic response of leaf explants cultured on the callus induction medium did not depend on the ploidy level of their parental plants. According to the flow cytometry analysis, the increased ploidy levels (4x) and ( $8 x)$ were observed in the callus cultures with diploid and tetraploid origin, respectively. A considerable difference was observed between the ploidy level of mixoploid plants and their calluses, indicating the dominance of diploid cells in the callus tissue. The results showed that polyploidy led to the loss of organogenic potential as the tetraploid origin calluses failed to regenerate, while the diploid origin calluses successfully regenerated to whole plants.
\end{abstract}

Keywords: Cichorium intybus, polyploidy, callus culture, organogenesis, flow cytometry.

Introduction. Polyploidy has played a major role in the evolution of many flowering plants and had a considerable impact on plant species diversity [1]. Recent estimates suggest that $70 \%$ of angiosperms have experienced one or more episodes of polyploidization [2]. Studies have demonstrated that polyploidy can result in a whole spectrum of genetic, molecular and physiological modifications [3] and is accompanied by a wide range of effects on plants, including significant enlargement of fruits and flowers, longer lasting time for flowers, overcoming barriers for hybridization, no seed or fewer seeds, enhancing pest resistance and stress tolerance [4].

Because of their significant role, polyploid species have been the subjects of many studies including in vitro cultures. Plant in vitro systems are valuable sources for the production of biological

(C) E. GHOTBI RAVANDI, F. REZANEJAD,

E. DEHGHAN, 2014 active substances and have promising applications in fundamental investigations of the molecular biology and biochemistry of plant cells [5].

The most important problem of in vitro cultures is to maintain the original genotype. One of the possible reasons for the differences between plant cells growing in vitro and in vivo is that in vitro cultivation may induce genetic diversification. Genetic instability, known as somaclonal variation, is especially pronounced if an undifferentiated callus phase is used [6]. Several factors have been found to influence somaclonal variation including type and concentration of applied plant growth regulators [7], degree of endopolyploidy of explants [8], duration of in vitro cultivation [9] and ploidy level, genotype and type of explant [10].

Ploidy level may also affect in vitro growth, development and regeneration ability of plants, so the comparison of regeneration capacity of polyploid tissues cultured in vitro with diploid tissues is especially of interest. So far, efficient regeneration systems among polyploids have been developed for Brassica napus [11], Solanum tuberosum L. [12] and Arabidopsis [9].

Cichorium intybus L., commonly known as chicory, is a biennial plant from the Asteraceae family. The whole plant (root, leaf and seed) is used medicinally. In vitro regeneration of $C$. intybus has been previously reported by several researchers through direct and indirect organogenesis or somatic embryogenesis using different explant types and various hormonal combinations [13-19].

In this paper, the correlation between the regeneration capacity and ploidy level of explants was examined and the ploidy level of the obtained calluses and regenerated plants in relation to their parental plants was also discussed.

Materials and methods. Plant material. Diploid seeds of $C$. intybus were provided from the Pakan Bazr Company located in Esfahan, Iran. Autotetraploid lines of $C$. intybus $(2 n=4 x=36)$ were obtained by treatment of apical meristems of 

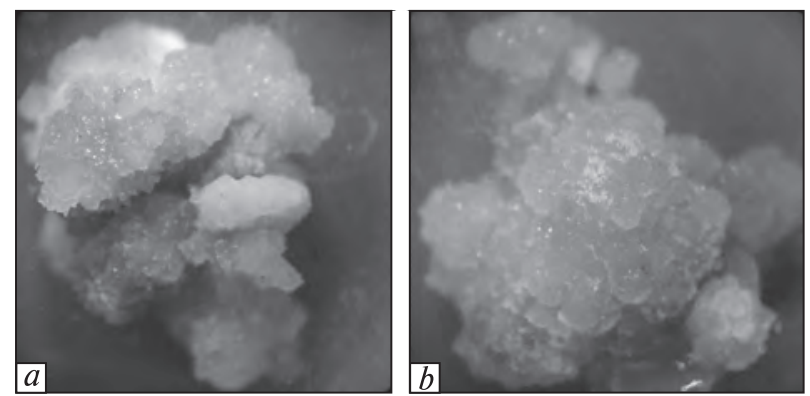

Fig. 1. Diploid $(a)$ and tetraploid $(b)$ origin calluses, after four weeks of culture

diploids with aqueous solutions of $0.05,0.1$ and $0.25 \%(\mathrm{w} / \mathrm{v})$ of colchicine at time intervals of 8 hours for four times and mixoploid plants were attained by soaking chicory seeds in $0.0075 \%$ colchicine solution for 72 hours, following a previously described procedure [20]. The ploidy level of plants was determined by flow cytometry analysis.

Establishment of callus cultures. Young actively growing healthy leaves of diploid, autotetraploid and mixoploid plants of chicory were selected as the sources of explants. These plants were 4 month old at the time of experiment. The leaves were surface sterilized by rinsing with $70 \%(\mathrm{v} / \mathrm{v})$ ethanol for $1 \mathrm{~min}$ followed by $5 \%(\mathrm{v} / \mathrm{v})$ sodium hypochlorite for 20 min. Afterwards, they were rinsed four times with sterile distilled water. All the explants were cut in to $1-1.5 \mathrm{~cm}$ pieces. About 1200 explants from 3 different diploid and tetraploid plants (200 explants from each plant) and 600 explants from 3 mixoploid plants with the almost similar ploidy levels (20-30\% diploid, 70-80\% tetraploid cells), were cultured on MS medium, enriched with $3 \%$ sucrose and $0.7 \%$ agar («Merck», Germany), supplemented with 1.5 $\mathrm{mg}^{-1} 1$-naphthalene acetic acid (NAA, «SigmaAldrich», USA) and $0.5 \mathrm{mg} \mathrm{l}^{-1}$ 6-benzylaminopurine (BAP, «Sigma-Aldrich», USA), at a growth chamber with $16 / 8$ hours light/dark photoperiod and $25{ }^{\circ} \mathrm{C}$. The obtained calluses were subcultured at 2 -week intervals for proliferation. After 5 weeks of culture, calluses were transferred to the shoot regeneration medium.

Shoot regeneration. The obtained calluses were cultured for shoot regeneration on MS medium supplemented with various concentrations and combinations of plant growth regulators including BAP, indole-3-acetic acid (IAA) and 2,4-dichlorophenoxy acetic acid (2,4-D) as followings: $1 \mathrm{mg} \mathrm{l}^{-1}$
$\mathrm{BAP}+0.25 \mathrm{mg} \mathrm{l}^{-1}$ and 2,4-D; $0.5 \mathrm{mg} \mathrm{l}^{-1} \mathrm{BAP}+$ $+0.25 \mathrm{mg} \mathrm{l}^{-1}$ and $2,4-\mathrm{D} ; 1 \mathrm{mg} \mathrm{l}^{-1} \mathrm{BAP}+0.25 \mathrm{mg} \mathrm{l}^{-1}$ IAA; $0.5 \mathrm{mg} \mathrm{l}^{-1}$ BAP $+0.25 \mathrm{mg} \mathrm{l}^{-1}$ IAA; 0.1, 0.5, 1 and $2 \mathrm{mg} \mathrm{l}^{-1}$ BAP.

Each treatment contained 50 explants in five replicates (10 explants per replicate). Explants were subcultured on to the similar fresh media every 3 weeks for further shoot regeneration and elongation for 9 weeks.

Root induction. Well-developed shoots $(2-3 \mathrm{~cm}$ long) with the average number of 3-4 leaves, were excised from the original explants and transferred to the rooting MS medium containing $1 \mathrm{mg}^{-1}$ NAA. Explants were subcultured on to similar fresh media every 4 weeks for root regeneration and elongation for 8 weeks. The complete in vitro cultures were incubated in a growth chamber at temperature of $25 \pm 2{ }^{\circ} \mathrm{C}$ and a photoperiod of $16 \mathrm{~h}$ light $/ 8 \mathrm{~h}$ darkness.

Flow cytometric analysis. In order to determine the ploidy level of the obtained calluses, their parental plants and the regenerated in vitro plants, flow cytometry analysis was conducted by a Partec PA flow cytometer. The samples were chopped using a sharp razor blade in $400 \mu$ nuclei extraction buffer (Kit A, suggested by Partec PA, Germany) for $30-60$ seconds. After filtration through a 30 $\mu \mathrm{m}$ Cell-Trice disposable filter (Partec, Germany), $1600 \mu \mathrm{l}$ of staining solution containing the dye 4-6-diamino-2-4-phenylindole (DAPI, provided by Partec PA, Germany as Kit B) was added and a minimum of 5000 nuclei were measured per sample and histograms of DNA content were generated using the Mode Fit software.

Results and Discussion. Callus induction. In the current experiment, the level of callogenesis of leaf explants were determined 5 weeks of culture and maintenance in similar conditions. Leaf explants responded very positively to the applied growth-regulator treatment, producing calluses after 2 weeks of culture on the callus initiation medium, supplemented with $1.5 \mathrm{mg} \mathrm{l}^{-1} \mathrm{NAA}$ and 0.5 $\mathrm{mg} \mathrm{l}^{-1}$ BAP. Callogenic response of diploid, tetraploid and mixoploid chicory plants were 98, 97 and $98 \%$ respectively. A similar result was obtained by Velayutham et al. [19] who reported that the same treatment could induce a high callus induction frequency $(96.7 \%)$ in leaf explants of diploid $C$. intybus. Though the higher growth rate of diploid calluses was expected, there was no 
discrimination between the morphology and growth rate of diploid and tetraploid origin calluses (Fig. 1). Furthermore, the callogenic response of leaf explants in the callus induction medium did not depend on the ploidy level of parental plants, as no visible difference was observed between the initiation time of callusing and callogenic rate of diploid and tetraploid origin explants.

Flow cytometry analysis. The flow cytometry analyses, conducted on the obtained calluses and their parental plants, produced histograms of DNA intensity, related to their expected ploidy level. In chicory, it seems that most cells of mature leaves were at G1 phase of the cell cycle as the G2 peak did not appear. The G1 peak of diploid plants was approximately at channel 20 (Fig. 2, a), whereas the G1 peak of tetraploids appeared at channel 40 (Fig. 2,b). The obtained flow cytometric histograms indicated the presence of $4 x$ cells in diploid origin calluses and $8 x$ cells in tetraploid origin ones (Fig. 3 ). The duplication of chromosome number in a portion of callus cells compared to their parental plants, can be due to the higher mitotic activity of undifferentiated cells of callus tissue which results in being a number of cells in G2 phase. Callus cultures of Kallstroemia pubescense [21], Crepis capillaris [22] and Larix $\times$ eurolepis [23], maintained the ploidy levels of the mother-plant material. In contrast, in seven-day callus culture of diploid Cucumis melo L, diploid, tetraploid and a small number of haploid, triploid and hexaploid cells were observed [24]. Fras et al. [25] explained that all callus lines of Arabidopsis thaliana exhibited a high level of polyploidization during callogenesis irrespective of their diploid or tetraploid origin.

Surprisingly, a considerable difference was observed between the ploidy level of mixoploid calluses $(80-90 \%$ diploid, $10-20 \%$ tetraploid cells) and their parental plants $(20-30 \%$ diploid, 70$80 \%$ tetraploid cells), demonstrating the gradual dominance of diploid cells to tetraploid ones in the callus tissues (Fig. 4). This can be explained by the fact that tetraploid cells require longer time to complete a cell cycle so the ratio of these two types of cells might not be stable and over time the $2 x$ cells predominate [26]. According to Tai [27] polyploid species show higher chances of forming multiple spindles, so it is also possible that tetraploid callus cells undergo mitotic abnormalities including amitosis or multiple spindles, as has been reported in

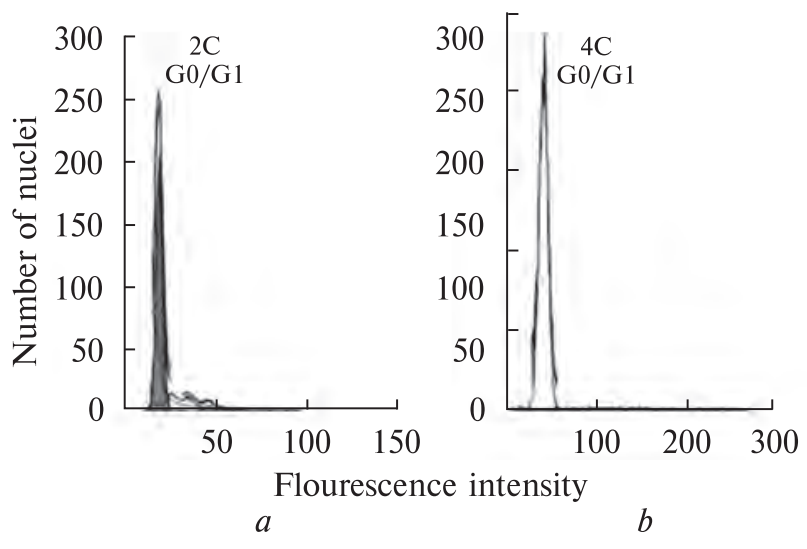

Fig. 2. Flow cytometric histograms of a diploid $(a)$ and tetraploid $(b)$ chicory plants

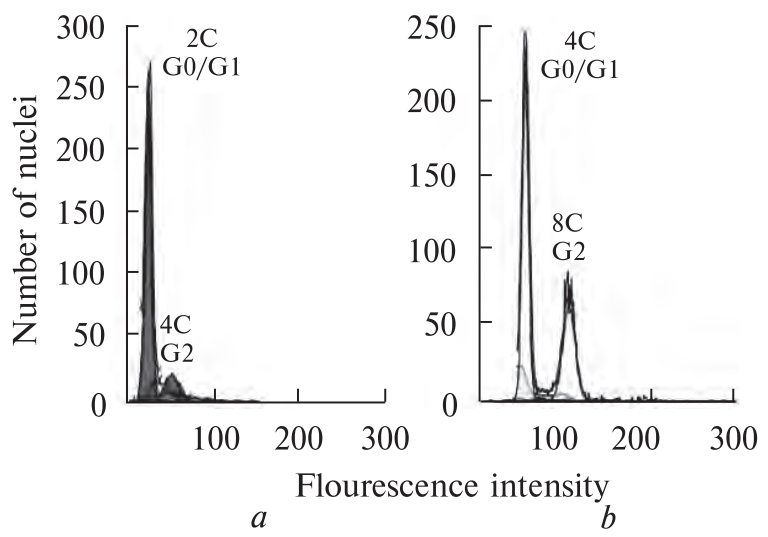

Fig. 3. Flow cytometric histograms of a diploid $(a)$ and tetraploid $(b)$ origin calluses

autotetraploid Brachiaria ruziziensis meiosis [28], leading to their diploidization.

Organogenic ability. Regenerated shoots were developed from diploid calluses with the differentiation rates of 54, 40 and $24 \%$ after 4 weeks of culture on the regeneration medium containing $0.5 \mathrm{mg}^{-1} \mathrm{BAP}$ $+0.25 \mathrm{mg} \mathrm{l}^{-1}$ IAA, $0.5 \mathrm{mg} \mathrm{l}^{-1} \mathrm{BAP}+0.25 \mathrm{mg} \mathrm{l}^{-1}$ and 2,4-D and $0.5 \mathrm{mg} \mathrm{l}^{-1}$ BAP, respectively (Fig. 5). All the other calluses, transferred to other shoot regeneration media, failed in regeneration. Root initiation was observed after 4 weeks of culture but complete root development took 8 weeks. About $52.5 \%$ rooting rate was recorded for the regenerated shoots. According to the flow cytometry analysis the whole regenerated plants were diploid.

The tetraploid origin calluses turned brown and failed to regenerate in the applied organogenic media after a long time culture (up to 9 weeks). The 


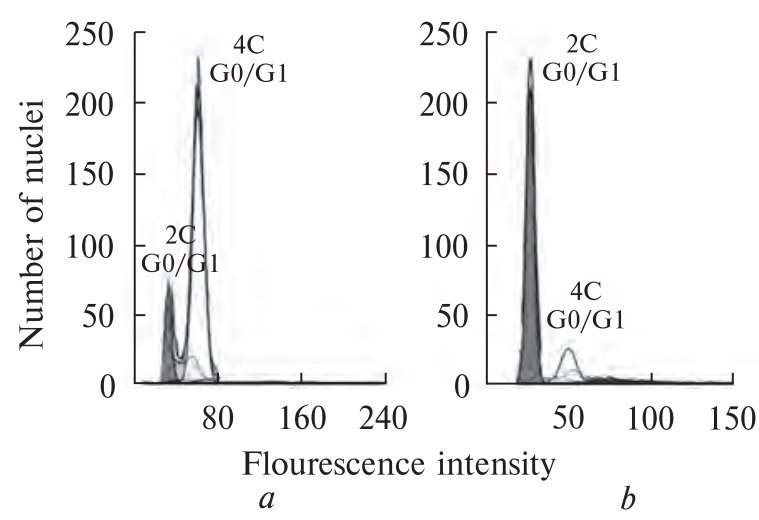

Fig. 4. Flow cytometric histograms of a mixoploid plant (21\% diploid $+79 \%$ tetraploid) $(a)$ and its obtained callus (88\% diploid $+12 \%$ tetraploid) $(b)$

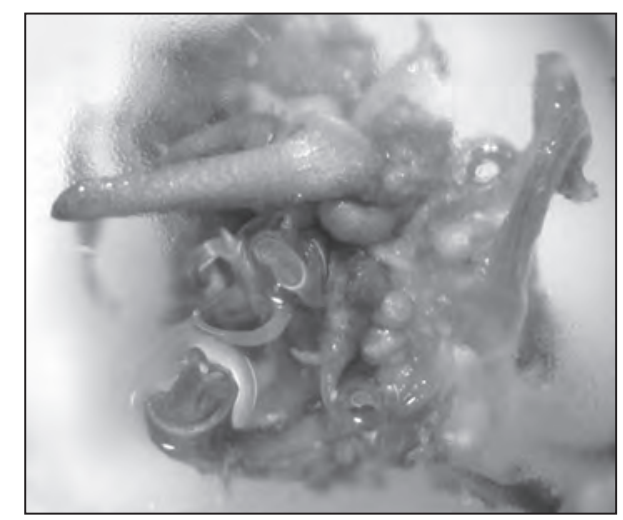

Fig. 5. Regenerated shoots from a diploid callus after 7 weeks of culture on the regeneration medium containing $0.5 \mathrm{mg} \mathrm{l}^{-1} \mathrm{BAP}+0.25 \mathrm{mg}^{-1}$ IAA

obtained result is in agreement with other reports indicating that polyploidization of cells had a strict relationship with decrease and loss of totipotency and in vitro organogenic potential. Kubalakova et al. [29] explained that polyploidization of callus cultures of Cucumis sativus L. resulted in gradual loss of regeneration ability as the regeneration rate of callus cultures was recorded 57, 18, $4 \%$ for diploids, tetraploids and octoploids, respectively. Sun et al. [30] reported that polyploidy in Pyrus communis was accompanied by reduction of in vitro shoot and root organogenesis.

Though it is unclear that what feature of autopolyploidy is responsible for this observation, several assumptions can be made. Tetraploidy is usually accompanied by doubling the genomic content and consequently the doubled cell volume but only a 1.6-fold increase in the nuclear envelope surface. This modest difference can result in a possible change of stoichiometry of the interaction between components of chromatin and envelopebound proteins and consequently dosage imbalance [31]. Polyploidization can also result in complicated rearrangements of chromosomes or changes in the structure of chromosomes, such as inversions and translocations [30]. These polyploidy-induced changes can be responsible for the changes in gene expression in polyploids. The effects of ploidy on gene regulation have been shown in several studies. The first such study measured the mRNA levels per genome for 18 genes in different ploidy levels of maize $(1 x, 2 x, 3 x$ and $4 x)$. Expression of most genes increased with ploidy as expected, but a few genes were ploidy-repressed [31]. Therefore it can be assumed that an alteration in mechanisms which regulate the gene expression or biosynthesis of plant growth regulators is caused by tetraploidy in $C$. intybus which may lead to the decreased or unbalanced levels of endogenous growth regulators, responsible for the loss of in vitro organogenic response of tetraploid origin calluses.

According to our previous study [20], tetraploid chicory plants showed a 1.9-time increase in total phenolic content of leaves compared with their diploid counterparts. It is possible that the increased content of total phenolic compounds in tetraploid origin calluses resulted in the loss of their organogenic potential. Phenolic compounds, especially oxidized phenolics, may contribute to the inhibition of enzymatic activities, resulting in the darkening of the culture medium and subsequent lethal browning of explants [32, 33]. It has been reported that oxidized phenolics generally affect in vitro proliferation and regeneration negatively [34].

Regenerated shoots appeared from $16 \%$ of mixoploid origin calluses, after 5 weeks of culture on the regenerating medium containing $0.5 \mathrm{mg} \mathrm{l}^{-1} \mathrm{BAP}$ $+0.25 \mathrm{mg} \mathrm{l}^{-1}$ and $2,4-\mathrm{D}$. The rooting rate was recorded $62.5 \%$ for the regenerated shoots. Flow cytometry analysis indicated the diploid level of the whole regenerated plants. The results of flow cytometry analysis of mixoploid origin calluses and their regenerated plants, indicated the diploidization of polyploid cells and the advantage of diploid cells in regeneration. Similar observation was reported for hypocotyl callus cultures of a polysomatic plant, Beta vulgaris, where a large number 
of diploid regenerants were obtained [35]. Several authors have reported that artificial tetraploids of Pisum sativum produced in vivo plants with the chromosome number reduced to the diploid level [36, 37]. Fras and Maluszynska [9] explained that most of the regenerants from all callus lines of tetraploid A. thaliana were diploids. Due to the failure of polyploid cells of mixoploid and tetraploid origin callus cultures of $C$. intybus in regeneration, it can be hypothesized that the shoot regeneration ability may act as a screen against induced polyploid cells and consequently diploid cells participate preferentially in plant regeneration.

Conclusion. The comparison of indirect organogenesis between diploid and tetraploid chicory plants indicated that while the callogenic response of leaf explants was not influenced by the ploidy level of their parental plants, the organogenic ability of the tetraploid origin calluses decreased compared to their diploid counterparts. The flow cytometry analysis showed the ploidy stability in diploid and tetraploid calluses but the number of diploid cells greatly increased in mixoploid calluses compared to their mixoploid parental plants. However, the molecular mechanism responsible for the loss of in vitro organogenesis in $C$. intybus is not clear and needs to be elucidated.

\section{E. Ghotbi Ravandi, F. Rezanejad, E. Dehghan}

\section{РЕГЕНЕРАЦИОННАЯ СПОСОБНОСТЬ ДИПЛОИДНЫХ И АВТОТЕТРАПЛОИДНЫХ РАСТЕНИЙ CICHORIUM INTYBUS L. IN VITRO}

Полиплоидия сыграла значительную роль в эволюционной истории растений как ценный инструмент получения полезных признаков. В настоящей работе приведено сравнение культурального ответа in vitro полиплоидов с диплоидами. Листовые экспланты диплоидных, автотетраплоидных и миксоплоидных растений Cichorium intybus L. культивировали на одних и тех же средах в одинаковых условиях. Уровень плоидности индуцированных каллусов и регенерантов определяли с помощью жидкостной цитометрии. Способность листовых эксплантов к каллусообразованию на среде для индукции каллуса не зависела от уровня плоидности исходных растений. По данным жидкостной цитометрии в каллусных культурах диплоидного и тетраплоидного происхождения наблюдалось увеличение уровней плоидности $(4 x$ и $8 x$ соответственно). Значительные отличия в уровнях плоидности обнаружены у миксоплоидных растений и их каллусов, при этом в каллусной ткани доми- нировали диплоидные клетки. Показано, что полиплоидия приводила к потере органогенного потенциала, так как тетраплоидные каллусы не были способны к регенерации, а в каллусах диплоидного происхождения успешно происходила регенерация растений.

\section{REFERENCES}

1. Wendel J., Doyle J. Polyploidy and evolution in plants // Plant diversity and evolution: Genotypic and phenotypic variation in higher plants / Ed. R.J. Henry. - CABI publ., 2005. - P. 97-117.

2. Masterson J. Stomatal size in fossil plants : Evidence for polyploidy in majority of angiosperms // Science. - 1994. - 264. - P. 421-424.

3. Adams K.L., Wendel J.F. Polyploidy and genome evolution in plants // Curr. Opin. Plant Biol. 2005. - 8. - P. 135-140.

4. Predieri $S$. Mutation induction and tissue culture in improving fruits // Plant Cell Tissue Organ. Cult. 2001. - 64. - P. 185-210.

5. Mulabagal V., Tsay H.S. Plant cell cultures an alternative and efficient source for the production of biologically important secondary metabolites // J. Appl. Sci. Eng. Tech. - 2004. - 2. - P. 29-48.

6. Palomino G., Dolezel J., Cid R. et al. Nuclear genome stability of Mammillaria san-angelensis (Cactaceae) regenerants induced by auxins in long-term in vitro culture // Plant Sci. - 1999. - 141. P. 191-200.

7. Mishiba K., Okamoto T., Mii M. Increasing ploidy level in cell suspension cultures of Doritaenopsis by exogenous application of 2,4-dichlorophenoxyacetic acid // Physiol. Plant - 2001. - 112. - P. 142-148.

8. Nontaswatsri C., Fukai $S$. Regenerative callus of Dianthus 'Telstar Scarlet' showing mixoploidy produce diploid plants // Plant Cell Tissue Organ. Cult. 2005. - 83. - P. 351-355.

9. Fras A., Maluszynska J. The correlation between the chromosome variation in callus and genotype of explants of Arabidopsis thaliana // Genetica. - 2004. 121. - P. 145-154.

10. $\operatorname{Karp} A$. The origins and causes of chromosome instability in plant // Kew Chromosome Conference III / Ed. P.E. Brandham - London, 1988. - P. 185192.

11. Ono Y., Takahata Y., Kaizuma N. Effect of genotype on shoot regeneration from cotyledonary explants of rapeseed (Brassica napus) // Plant Cell Rep. - 1994. 14. - P. 13-17.

12. Garcia E., Martinez S. Somatic embryogenesis in $S_{0-}$ lanum tuberosum $\mathrm{L}$. cv. desiree from stem nodal sections // J. Plant Physiol. - 1995. - 145. - P. 526530.

13. Profumo P., Gastaldo P., Caffaro L. et al. Callus in- 


\section{E. Ghotbi Ravandi, F. Rezanejad, E. Dehghan}

duction and plantlet regeneration in Cichorium intybus L.: 2. Effect of different hormonal treatments // Protoplasma - 1985. - 126. - P. 215-220.

14. Pieron S., Belaizi M., Boxus P. Nodule culture, a possible morphogenetic pathway in Cichorium intybus L. propagation // Sci. Hort. - 1993. - 53. - P. 111.

15. Vesseur J., Dubois J., Hilbert J.L. Couillerot J.P. Somatic embryogenesis in chicory (Cichorium intybus L.) // Biotechnology and agricultural forestry: somatic embryogenesis and synthetic seeds II / Ed. Y.P.S. Bajaj. Berlin : Springer, 1995. - P. 125-137.

16. Belletre A., Coullerot J.P., Vasseur J. Effects of glycerol on somatic embryogenesis in Cichorium leaves // Plant Cell Rep. - 1999. - 19. - P. 26-31.

17. Rehman R.U., Israr M., Srivastava P.S. et al. In vitro regeneration of witloof chicory (Cichorium intybus L.) from leaf explants and accumulation of esculin // In vitro Cell Dev. Biol. Plant. - 2003. - 39. P. 142-146.

18. Bennici A., Schiff S. Mori B. Morphogenic effect of colchicine in Cichorium intybus L. root explants cultured in vitro // Caryologia. - 2006. - 59. - P. 284290.

19. Velayutham P., Ranjithakumari B.D., Baskaran P. An efficient in vitro plant regeneration system for Cichorium intybus L. - an important medicinal plant // J. Agr. Technol. - 2007. - 2, № 2. - P. 287-298.

20. Ghotbi Ravandi E., Rezanejad F., Zolala J., Dehghan $E$. The effects of chromosome-doubling on selected morphological and phytochemical characteristics of Cichorium intybus L. // J. Hor. Sci. Biotech. - 2013. 88. - P. 701-709.

21. Sengupta J., Mitra G.C., Sharma A.K. Study of chromosomes in two callus lines and in regenerated plants of Kallstroemia-Pubescens G. Don Dandy // Cytologia. - 1987. - 52. - P. 767-770.

22. Maluszynska J. B chromosomes of Crepis capillaris (L.) Waller. in vivo and in vitro // Prace Naukowe Uniwersytetu Slaskiego. - Katowice, 1990.

23. Wyman J., Brassard N., Flipo D., Lalibert S. Ploidy level stability of callus tissue, axillary and adventitious shoots of Larix $\times$ eurolepis Henry regenerated in vitro // Plant Sci. - 1992. - 85. - P. 189-196.

24. Ezura H., Oosawa K. Selective regeneration of plants from diploid and tetraploid cells in adventitious shoot cultures of Melon Cucumis melo L. // Plant Tissue Cult. Lett. - 1994. - 11, № 1. - P. 26-33.

25. Fras A., Poliploidalnos C.W. Kulturze in vitro Ara- bidopsis thaliana : Ph.D. dissertation. - Katowice : Univ. Silesia, 2001.

26. Nilanthi D., Chen X., Zhao F. et al. Induction of tetraploids from petiole explants through colchicine treatments in Echinacea purpurea L. // J. Biomed. Biotechnol. - 2009. - Article ID343485. - 7 p.

27. Tai $W$. Multipolar meiosis in diploid crested wheatgrass Agropyrum cristatum // Amer. J. Bot. - 1970. 57. - P. 1160-1169.

28. Risso-Pascotto C., Pagliarini M.S., Do Valle C.B. Multiple spindles and cellularization during microsporogenesis in an artificially induced tetraploid accession of Brachiaria ruziziensis (Gramineae) // Plant Cell Rep. - 2005. - 23. - P. 522-527.

29. Kubalakova M., Dolezel J., Lebeda A. Ploidy instability of embryogenic cucumber (Cucumis sativus L.) callus culture // Biol. Plant. - 1996. - 38, № 3. P. 475-480.

30. Sun Q., Sun H., Bell R.L. et al. Variation of phenotype, ploidy level and organogenic potential of in vitro regenerated polyploids of Pyrus communis // Plant Cell Tissue Organ. Cult. - 2011. - 107. - P. 131140.

31. Comai $L$. The advantages and disadvantages of being polyploid // Nat. Rev. Genet. - 2005. - 6. P. 836-846.

32. Compton M.E., Preece J.E. Exudation and explant establishment // IAPTC Newsl. - 1986. - 50. P. 9-18.

33. Laukkanen H., Häggman H., Kontunen-Soppela S., Hohtola A. tissue browning of in vitro cultures of scots pine: role of peroxidase and polyphenol oxidase // Physiol. Plant. - 1999. - 106. - P. 337-343.

34. Arnaldos T.L., Munoz R., Ferrer M.A. Calderon A.A. Changes in phenol content during strawberry (Fragaria $\times$ Ananasa, Cv. Chandler) callus culture // Physiol. Plant - 2001. - 113. - P. 315-322.

35. Jacq B., Tétu T., Sangwan R.S. et al. Plant regeneration from sugarbeet (Beta vulgaris L.) hypocotyls cultured in vitro and flow cytometric nuclear DNA analysis of regenerants // Plant Cell Rep. - 1992. 11. - P. 329-333.

36. Kasperek G. Artificial polyploids of the pea // Pisum Newsl. - 1986. - 18. - P. 32.

37. Gottschalk W. Tetraploidy following X-radiation // Pisum Newsl. - 1988. - 20. - P. 14-15.

Received 12.11.12 